\title{
Interactive comment on "A Conceptual framework for web-based Nepalese landslide information system" by Sansar Raj Meena et al.
}

\section{Sansar Raj Meena et al. \\ sansarraj.meena@sbg.ac.at}

Received and published: 23 September 2019

Dear Reviewer, We very much appreciate your positive statements regarding our manuscript. We are appreciative of your time and the detailed comments. In fact, you brought up interesting aspects, and we believe that these comments and our respective reactions to them will improve the quality of the paper. We did our best to improve the scientific quality of the manuscript significantly. Responses to each comment or suggestion are marked with track changes in manuscript. Please find the attached document for detailed responses in the supplement.

Printer-friendly version

Discussion paper

Best Regards

Sansar Raj Meena 
Please also note the supplement to this comment:

NHESSD

https://www.nat-hazards-earth-syst-sci-discuss.net/nhess-2019-246/nhess-2019-246AC2-supplement.zip

Interactive comment on Nat. Hazards Earth Syst. Sci. Discuss., https://doi.org/10.5194/nhess-

Interactive

comment 2019-246, 2019. 